\title{
Review
}

\section{Nano-Elicitation as an Effective and Emerging Strategy for In Vitro Production of Industrially Important Flavonoids}

\author{
Amna Komal Khan ${ }^{1}$, Sidra Kousar ${ }^{2}$, Duangjai Tungmunnithum ${ }^{3} \oplus$, Christophe Hano ${ }^{4} \oplus$, Bilal Haider Abbasi ${ }^{5} \mathbb{C}$ \\ and Sumaira Anjum $1, *$ (1) \\ 1 Department of Biotechnology, Kinnaird College for Women Lahore, Lahore 54000, Pakistan; \\ aaykay28@gmail.com \\ 2 Department of Chemistry, University of Agriculture Faisalabad, Punjab 38000, Pakistan; \\ Sidrakousar27@gmail.com \\ 3 Department of Pharmaceutical Botany, Faculty of Pharmacy, Mahidol University, Bangkok 10400, Thailand; \\ duangjai.tun@mahidol.ac.th \\ 4 Laboratoire de Biologie des Ligneux et des Grandes Cultures (LBLGC), INRAe USC1328, \\ Université d'Orléans, 28000 Chartres, France; hano@univ-orleans.fr \\ 5 Department of Biotechnology, Quaid-i-Azam University Islamabad, Islamabad 54000, Pakistan; \\ bhabbasi@qau.edu.pk \\ * Correspondence: sumaira.anjum@kinnaird.edu.pk; Tel.: +92-300-6957038
}

check for

updates

Citation: Khan, A.K.; Kousar, S.; Tungmunnithum, D.; Hano, C.;

Abbasi, B.H.; Anjum, S.

Nano-Elicitation as an Effective and Emerging Strategy for In Vitro Production of Industrially Important Flavonoids. Appl. Sci. 2021, 11, 1694. https://doi.org/10.3390/app11041694

Academic Editor: Susana

Santos Braga

Received: 30 December 2020

Accepted: 11 February 2021

Published: 14 February 2021

Publisher's Note: MDPI stays neutral with regard to jurisdictional claims in published maps and institutional affiliations.

Copyright: (c) 2021 by the authors. Licensee MDPI, Basel, Switzerland. This article is an open access article distributed under the terms and conditions of the Creative Commons Attribution (CC BY) license (https:/ / creativecommons.org/licenses/by/ $4.0 /)$.
Featured Application: Nanoparticles (NPs) emerged as novel and effective elicitors for increasing the production of industrially important flavonoids.

\begin{abstract}
Flavonoids represent a popular class of industrially important bioactive compounds. They possess valuable health-benefiting and disease preventing properties, and therefore they are an important component of the pharmaceutical, nutraceutical, cosmetical and medicinal industries. Moreover, flavonoids possess significant antiallergic, antihepatotoxic, anti-inflammatory, antioxidant, antitumor, antiviral, and antibacterial as well as cardio-protective activities. Due to these properties, there is a rise in global demand for flavonoids, forming a significant part of the world market. However, obtaining flavonoids directly from plants has some limitations, such as low quantity, poor extraction, over-exploitation, time consuming process and loss of flora. Henceforth, there is a shift towards the in vitro production of flavonoids using the plant tissue culture technique to achieve better yields in less time. In order to achieve the productivity of flavonoids at an industrially competitive level, elicitation is a useful tool. The elicitation of in vitro cultures induces stressful conditions to plants, activates the plant defense system and enhances the accumulation of secondary metabolites in higher quantities. In this regard, nanoparticles (NPs) have emerged as novel and effective elicitors for enhancing the in vitro production of industrially important flavonoids. Different classes of NPs, including metallic NPs (silver and copper), metallic oxide NPs (copper oxide, iron oxide, zinc oxide, silicon dioxide) and carbon nanotubes, are widely reported as nano-elicitors of flavonoids discussed herein. Lastly, the mechanisms of NPs as well as knowledge gaps in the area of the nano-elicitation of flavonoids have been highlighted in this review.
\end{abstract}

Keywords: flavonoids; nanoparticles; elicitation; biotechnology; plant secondary metabolites

\section{Introduction}

Flavonoids are plant secondary metabolites which have gained importance in the biotechnology industry due to their unique health related properties [1]. They are found in almost all of the growing parts of plants responsible for the pigmentation of fruits, flowers and leaves. Moreover, flavonoids such as anthocyanins, tannins and phytoalexins impart protection to plants against ultraviolet radiation, herbivores and pathogens, respectively [2]. Besides their relevance in plants, flavonoids are also associated with a 
vast spectrum of health enhancing effects and are an indispensable component in a variety of pharmaceutical, nutraceutical, cosmetical and medical applications [3,4]. Flavonoids possess significant antiallergic, antihepatotoxic, anti-inflammatory, antioxidant, antitumor, antiviral, antibacterial, antiosteoporosis as well as cardio-protective activity. Antioxidant, antihepatotoxic, anti-inflammatory, antiallergic, antitumor, antiosteoporosis, antiviral, antibacterial and cardio-protective potential have been reported in many flavonoids from various plant species [5-9]. In vivo studies also support the possible use of flavonoid rich plants in treating diseases. Recently, Bergamot juice, which is rich in flavonoid content, was used to treat experimental periodontitis in rats. The results showed that flavonoids present in Bergamot juice reduced the expression of inflammatory markers associated with gingival inflammation, and downregulated NF- $\mathrm{KB}$ activation as well as apoptosis [4]. Therefore, when consumed in the human diet, these compounds promote health and prevent diseases $[4,5]$. Flavonoids also influence the quality and stability of food as they add flavor and color to food and act as a food preservative [10]. These properties make flavonoids an important commercial biomolecule, which has led to attempts for the in vitro production of flavonoids via the plant tissue culturing technique.

Plants are capable of synthesizing an overwhelming variety of low molecular weight organic compounds, called plant secondary metabolites or plant specialized metabolites, which help plants to colonize diverse and challenging environments [11]. Currently, about 100,000 such compounds have been isolated from plants classified into major groups, which include terpenes, phenolics and alkaloids [12]. Flavonoids form a part of a large group of phenolic compounds and an essential component of plant cells [13]. Phenolic compounds have one or more hydroxyl groups attached directly to an aromatic ring, while their subgroup, flavonoids, is characterized by the presence of 15 carbon atoms in the flavonoids' basic skeleton containing two aromatic rings. The carbon atoms in flavonoids are arranged in C6-C3-C6 form, which corresponds to two aromatic compounds linked together via three carbon atoms $[14,15]$. The arrangement of the $C_{3}$ group determines the classification of flavonoids, giving rise to three classes: flavonoids, isoflavonoids and neoflavonoids [16] (Figure 1). The biosynthesis of flavonoids is initiated by the condensation of one $p$-coumaroyl-CoA molecule with three molecules of malonyl-CoA in the presence of chalcone synthase to form chalcone. Chalcone is isomerized by an enzyme chalcone isomerase, which converts chalcones to flavanones. From these intermediate compounds, the pathway diverges into several side branches, each giving rise to a different class of flavonoids [17].

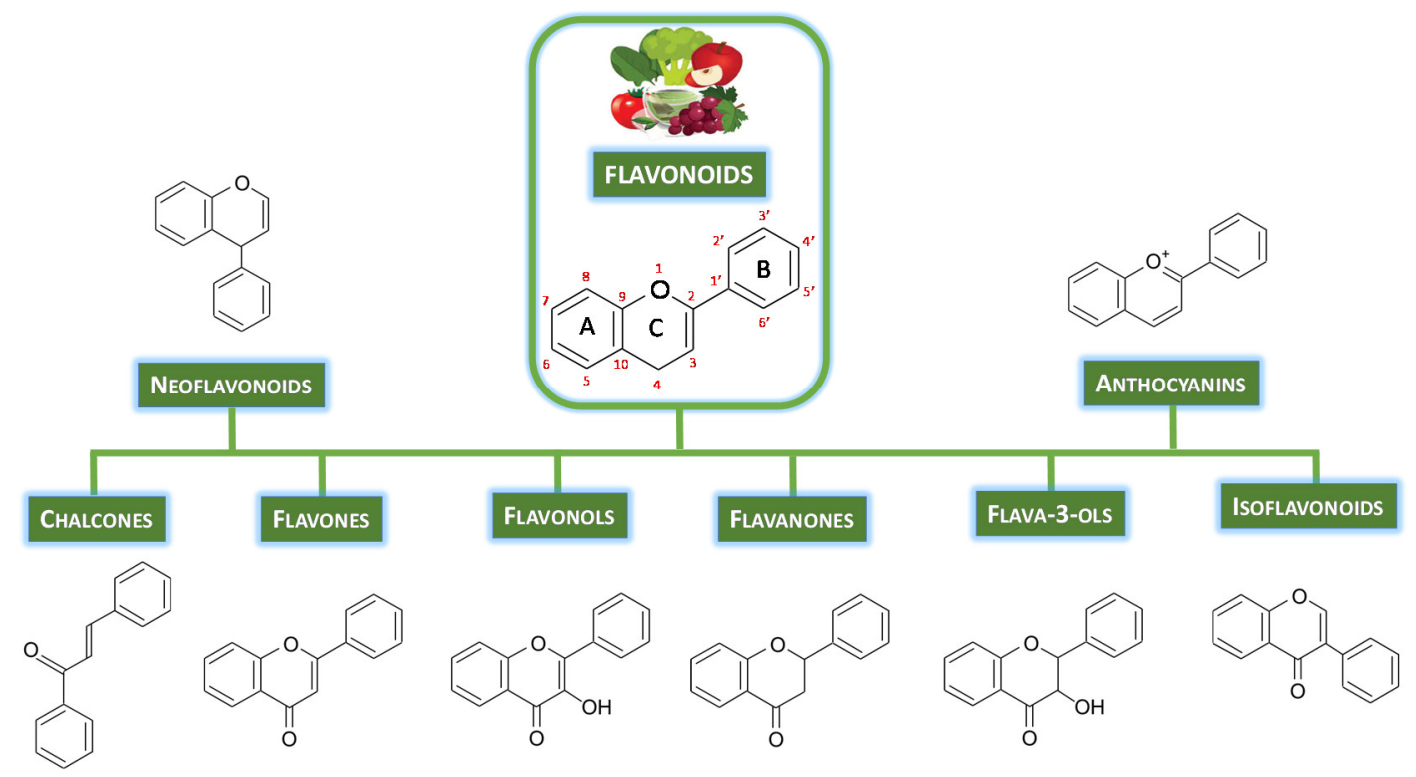

Figure 1. Flavonoids' structures and classification. 
Recently, medicinal plants have been exploited for flavonoids to treat human maladies naturally [18]. With the rise in industrial demand for bioactive compounds from medicinal plants, there is a shift towards the use of in vitro culture systems for the mass production of secondary metabolites in a shorter time. The in vitro culturing technique avoids the destruction of plants' natural habitat, cutting down plant roots or underground parts and the over-exploitation of wild species [19]. Most prominently, callus and cell suspension cultures of several plants have been established for the enriched production of flavonoids. Both culture types ensure homogeneity in in vitro cell culture, a higher growth rate and productivity, as well as good reproducibility [20]. In addition to this, transgenic hairy root cell lines for the stable production of flavonoids have also been established [21]. Despite the successful in vitro production of plant secondary metabolites, there are still some bottlenecks, such as inconsistent yield, poor quality and lower productivity for large scale cultivation. To counter this, biotechnologists have devised different strategies to enhance the production of secondary metabolites in in vitro cultures, such as media modification, genetic engineering, precursor feeding, screening of high yielding cell lines, bioreactors, immobilization, biotransformation and elicitation [22].

Among different strategies, elicitation is the best known and effective yield enhancement strategy. Elicitation is the addition of exogenous elicitors, which are compounds that stimulate any type of plant defense and promote plant secondary metabolism to impart protection to the plant against stress [23]. Elicitors are perceived by specific receptors/ion channels in the plasma membrane, trigger gene expression and induce a stress response in plants, which may result in the production of higher amounts or new forms of valuable secondary metabolites [24]. To date, different types of biotic and abiotic elicitors have been used for the elicitation of plant secondary metabolism. Among different elicitors, nanoparticles (NPs) showed a great potential to act as novel elicitors of flavonoids in plants due to their unique properties. Currently, different types of NPs have been used as novel and effective elicitors of flavonoids in in vitro cultures of various plant species, as shown in Figure 2 [25]. Different types of NPs, including metallic NPs, metal oxide NPs and carbon-related NPs, are widely reported as novel elicitors of flavonoids. These NPs include silver NPs (AgNPs), copper NPs (CuNPs), iron oxide NPs $\left(\mathrm{Fe}_{3} \mathrm{O}_{4} \mathrm{NPs}\right)$, zinc oxide NPs (ZnONPs), copper oxide NPs (CuONPs), carbon nanotubes and chitosan based NPs [26]. In this review, an in-depth literature on the role of NPs as elicitors of industrially important flavonoids has been critically reviewed, along with the mechanism of nano-elicitation. Furthermore, the review is concluded with future directions.

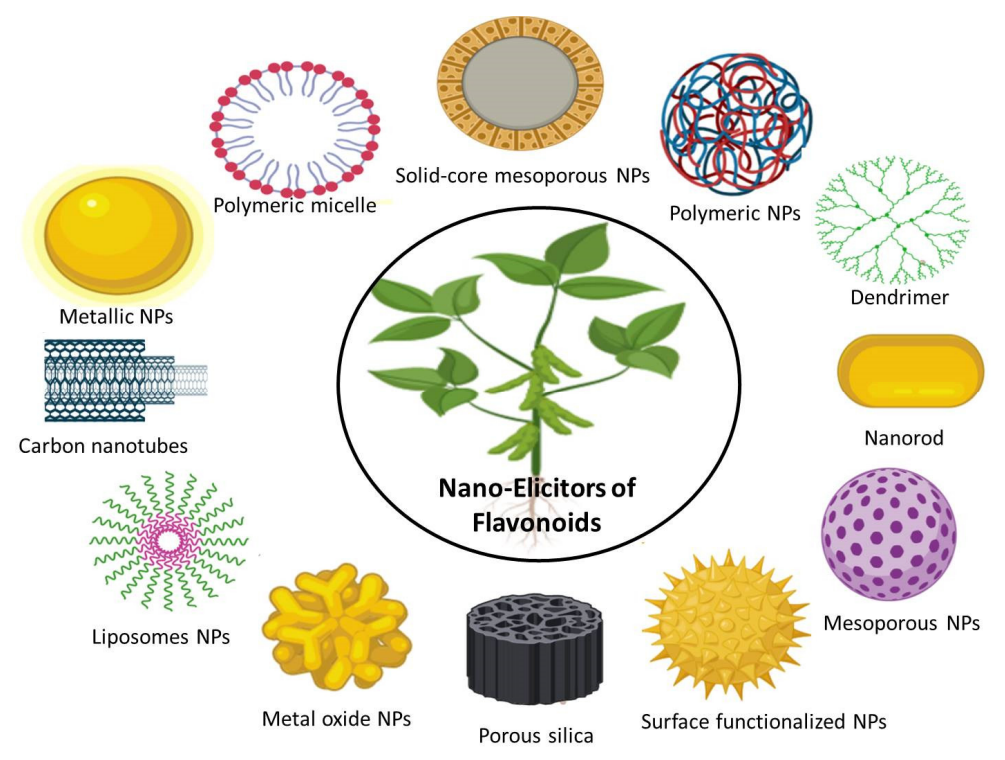

Figure 2. Graphical representation of different types of nano-elicitors of commercially important flavonoids in various in vitro systems of plants (NPs: nanoparticles). 


\section{Mechanism of Nano-Elicitation}

Since little is known about most of plant secondary metabolism, the effects of elicitors on plant cells or tissue cultures are therefore difficult to gauge. The mechanism employed by elicitors is complex and distinctive. Elicitors act as a signal which is received by the elicitor specific receptors located on plasma membranes [27]. Several elicitor-binding sites have been identified in cell plasma membranes for a range of elicitors. Transmembrane receptor-like protein kinases (RLKs) are one of the well-known categories of receptors which might be concerned with the perception of different types of stimuli [28]. NPs can directly bind receptors (e.g., chitosan-NPs) and/or trigger the production of the second endogenous messenger that could bind to these receptors [20].

After the binding of receptor-NPs, the initial response to NPs involves an active exchange of ions, i.e., $\mathrm{Cl}^{-}$and $\mathrm{K}^{+}$efflux and $\mathrm{Ca}^{2+}$ influx occur across the cell membrane into the cytosol, as shown in Figure 3. $\mathrm{Ca}^{2+}$ influx is an important step during the elicitation process as it further modulates various physiological and cellular pathways. Cytoplasm acidification occurs in response to H+-ATPase inactivation and an increase in extracellular $\mathrm{pH}$. Cytoplasmic acidification is important for signal transduction, leading to the oxidative burst and biosynthesis of plant secondary metabolites.

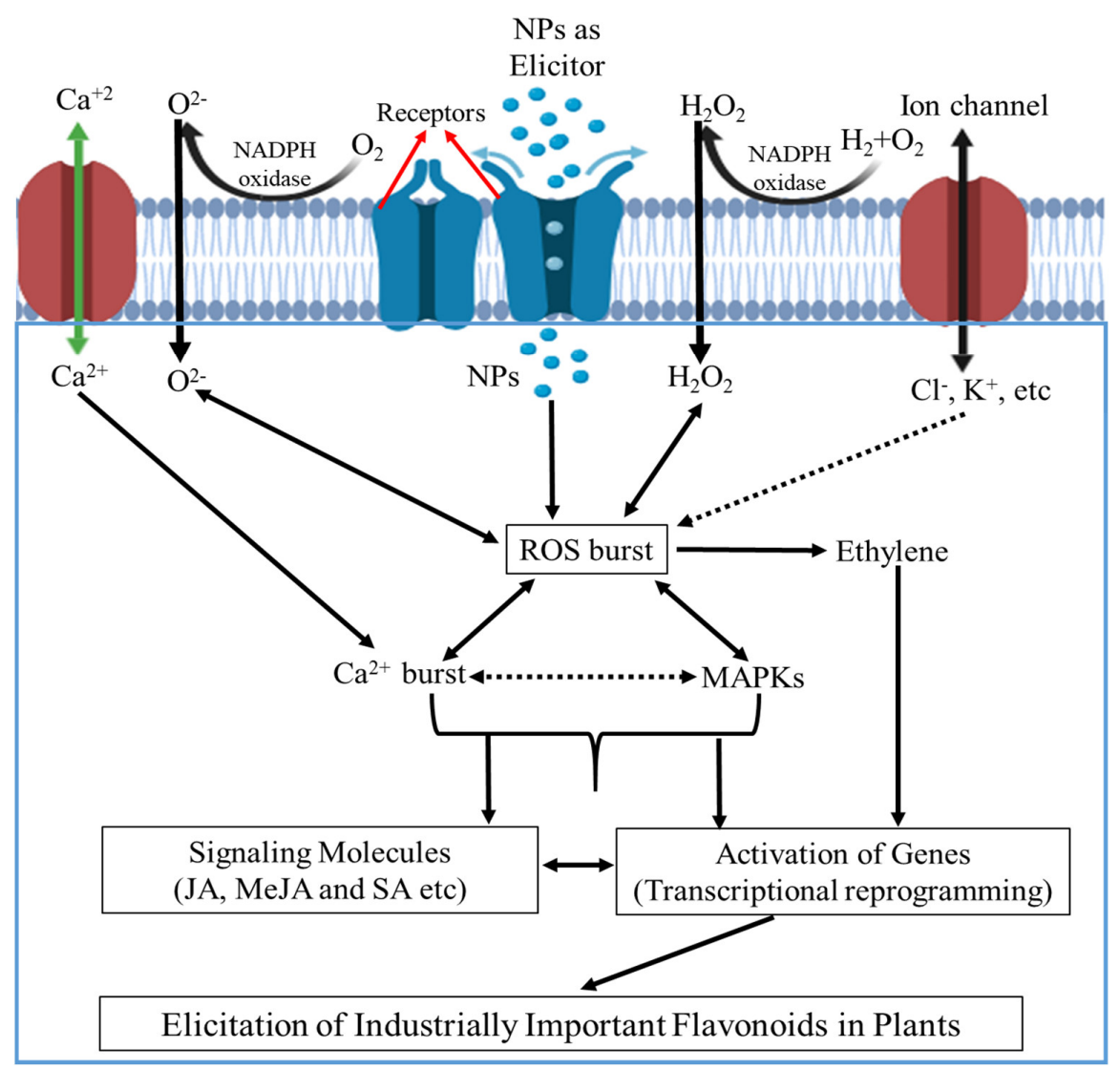

Figure 3. Representation of a proposed mechanism involved in nano-elicitation of commercially important flavonoids in various in vitro systems of plants (Note: dashed arrows indicate indirect reactions and the continuous arrows indicate direct ones; ROS: reactive oxygen species; MAPKs: mitogen-activated protein kinases; NPs: nanoparticles; JA: jasmonate; MeJA: methyl jasmonate; SA: salicylic acid).

These events lead to reversible phosphorylation and dephosphorylation of plasma membrane proteins and cytosolic proteins and the activation of protein kinases (PK) and mitogen-activated protein kinases (MAPK). The involvement of GTP binding proteins (G-proteins) during elicitation is also reported. G-proteins probably respond by 
activating phospholipases, leading to the downstream production of plant secondary metabolites [29-31].

The PLC (phospholipase-C)/IP3-DAG (Inositol trisphosphate- diacylglycerol)/PKC (protein kinase $\mathrm{C}$ ) cascade also plays a key role during elicitation. The second calcium influx occurs due to PLC activation and inositol triphosphate (IP3) released $\mathrm{Ca}^{2+}$ from intracellular calcium stores, such as the vacuoles, Golgi apparatus, and endoplasmic reticulum [32]. The increase in cytoplasmic calcium levels activates the defense response, either directly by calcium or through calcium sensors, such as calmodulins and $\mathrm{Ca}^{2+}$-dependent protein kinases (CDPKs). Increased intracellular $\mathrm{Ca}^{2+}$ level activates NADPH oxidase and the subsequent generation of ROS (reactive oxygen species) [20]. ROS induces the expression of many defense genes and secondary metabolite biosynthetic genes, such as phenylalanine ammonia lyase (PAL), and the induction of signaling molecules, such as salicylic acid (SA), ethylene (EA) and jasmonate (JA). These signaling molecules further activate the pathways of secondary metabolite production in plant cells [33].

Several factors such as the concentration of an elicitor, the morphology of an elicitor, exposure time, the type of in vitro culture, nutrient composition, growth regulators and plant species influence the production of secondary metabolites [25].

\section{Nano-Elicitation of Flavonoids}

In last few years, a variety of nanomaterials have been reported for the elicitation of flavonoids in different in vitro cultures of plant species.

\subsection{AgNPs as a Novel Elicitor of Flavonoids}

AgNPs find their applications in medicine, biotechnology and agriculture owing to their desirable physico-chemical properties [34]. Amongst different NPs, AgNPs are widely reported as a novel elicitor of flavonoids in in vitro culture (Table 1). Momordica charantia, commonly known as bitter gourd, is a highly nutritive vegetable containing bioactive compounds such as phenolics and flavonoids [35]. The cell suspension culture of $M$. charantia was elicited with Bacillus licheniformis biosynthesized AgNPs (50 nm) at $5 \mathrm{mg} / \mathrm{L}$ concentration. The elicited culture showed enhanced concentration of different flavonoids including quercetin, kaempferol, catechin, myricetin, rutin, naringenin and biochanin A [36]. Flavonols are the most ubiquitous flavonoids found in food, also called 3-hydroxylavones. They are closely related to flavones in structure but differ in having a hydroxyl group at 3-position on the C-ring, while flavones contain a ketone group with an unsaturated carbon-carbon bond [37]. Quercetin, being the most abundant flavonol in plants, possesses anti-inflammatory, anti-oxidative and anticancer activities, and it is therefore a widely studied flavonoid. As quercetin has a special ability to scavenge highly reactive species such as hydroxyl radical, so it has importance as a nutraceutical [38]. The hairy root culture of Cucumis anguria when elicited with AgNPs showed an increase in the accumulation of phenolic compounds as well as flavonoid compounds. AgNP elicited culture showed a higher amount of flavonols $(3136.20 \mu \mathrm{g} / \mathrm{g})$ as compared to non-elicited culture [39]. Similarly, biogenic AgNPs effectively elicited the hairy root culture of Brassica rapa at concentrations 50,100, and $150 \mathrm{mg} / \mathrm{L}$. Hairy roots treated with $100 \mathrm{mg} / \mathrm{L} \mathrm{AgNP}$ solution showed a gradual increase in the concentration of total phenolic content (TPC) and total flavonoid content (TFC), while treatment with $150 \mathrm{mg} / \mathrm{L}$ decreased TPC and TFC. Moreover, nine different types of flavonoids (myricetin, naringenin, catechin, quercetin, rutin, kaempferol, biochanin A, formononetin, and hesperidin) were accumulated in a higher quantity in AgNP elicited culture [40].

The influence of biologically synthesized polydispersed AgNPs from a pod extract of Cola nitida on the phytochemical profile of Amaranthus caudatus plant was investigated. There was $32.58,35.80$, and $7.20 \%$ improvement in flavonoid content for 25,50 and $100 \mathrm{ppm}$ concentration of AgNPs, respectively. Moreover, kaempferol and quercetin were the most abundant flavonols produced at $50 \mathrm{ppm}$ AgNP concentration [41]. The callus culture of Caralluma tuberculata when elicited with $90 \mathrm{ug} / \mathrm{L} \mathrm{AgNPs}(40 \mathrm{~nm})$ led to $1.8 \mathrm{mg}$ TFC 
production [42]. Caralluma tuberculata contains valuable bioactive compounds mostly used to treat diabetes, asthma, paralysis, inflammation, obesity and fever [43].

Anthocyanins are another member of the flavonoids family which have angiocardiopathy, high antioxidant and cancer prevention properties [44]. Anthocyanins are water soluble colored pigments which have been used as food pigments, nutraceuticals and traditional medicine [45]. When the seedlings of Arabidopsis thaliana were elicited with $50 \mu \mathrm{M}$ spherical shaped AgNPs, a 56\% increase in anthocyanins was observed. Moreover, anthocyanin accumulation was correlated with the increase in the expression of antioxidant enzyme $\mathrm{Cu} / \mathrm{Zn}$ superoxide dismutase 2 [46].

When the cell suspension culture of Linum usitatissimum was elicited with AgNPs during the early phase, enhanced flavonoid production was observed, which declined during the later phase, and the highest TFC (11.85 mg/g dry weight (DW)) was recorded when cultures were elicited on day 10 [47]. A possible reprogramming of the phenylpropanoid pathway through this AgNPs elicitation was suggested since the accumulation of other phenylpropanoids such as lignans and neolignans was also affected [47].

Table 1. Role of silver NPs (AgNPs) as an elicitor of flavonoids.

\begin{tabular}{|c|c|c|c|c|c|c|}
\hline Plant Species & $\begin{array}{l}\text { Type of In Vitro } \\
\text { Culture }\end{array}$ & Growth Media & $\begin{array}{l}\text { NP Size } \\
(\mathrm{nm})\end{array}$ & $\begin{array}{c}\text { Effective } \\
\text { Concentration } \\
\text { of NPs }\end{array}$ & Effect on Flavonoid Production & References \\
\hline M. charantia & $\begin{array}{l}\text { Cell suspension } \\
\text { culture }\end{array}$ & MS media & 50 & $5 \mathrm{mg} / \mathrm{L}$ & $\begin{array}{c}\text { Enhanced production of } \\
\text { quercetin, kaempferol, catechin, } \\
\text { myricetin, rutin, naringenin and } \\
\text { biochanin A. }\end{array}$ & [36] \\
\hline C. anguria & Hairy root & MS media & - & $2.0 \mathrm{mg} / \mathrm{L}$ & $\begin{array}{l}\text { Increase in flavonol production. } \\
\text { Increase in TFC and }\end{array}$ & [39] \\
\hline B. rapa & Hairy root & MS media & $2-10$ & $100 \mathrm{mg} / \mathrm{L}$ & $\begin{array}{l}\text { accumulation of myricetin, } \\
\text { naringenin, catechin, quercetin, } \\
\text { rutin, kaempferol, biochanin } \mathrm{A} \text {, } \\
\text { formononetin, and hesperidin. }\end{array}$ & [40] \\
\hline A. caudatus & Whole plant & Garden soil & $17-91$ & $50 \mathrm{ppm}$ & $\begin{array}{l}\text { Improved flavonoid } \\
\text { accumulation, predominantly } \\
\text { kaempferol and quercetin. }\end{array}$ & [41] \\
\hline C. tuberculata & Callus & $\begin{array}{l}\text { MS media with } \\
\text { 2,4-D and BA }\end{array}$ & 40 & $90 \mu \mathrm{g} / \mathrm{mL}$ & $1.8 \mathrm{mg}$ TFC production. & [42] \\
\hline $\begin{array}{l}\text { A. thaliana } \\
\text { L. usitatissimum }\end{array}$ & $\begin{array}{l}\text { Seedlings } \\
\text { Cell suspension }\end{array}$ & $\begin{array}{l}\text { MS media } \\
\text { MS media }\end{array}$ & $\begin{array}{c}8-47 \\
18\end{array}$ & $\begin{array}{c}50 \mu \mathrm{M} \\
-\end{array}$ & $\begin{array}{l}56 \% \text { increase in anthocyanins. } \\
\text { TFC was } 11.85 \mathrm{mg} / \mathrm{g} \mathrm{DW}\end{array}$ & $\begin{array}{l}{[46]} \\
{[47]}\end{array}$ \\
\hline \multirow[t]{2}{*}{ P. vulgaris } & Callus & $\begin{array}{l}\text { MS media with } \\
\text { NAA }\end{array}$ & $\mathrm{Ag}+\mathrm{Au}$ & 1:3 ratio & Enhanced TFC. & [48] \\
\hline & Cell suspension & $\begin{array}{l}\text { MS Media with } \\
\text { NAA }\end{array}$ & $\mathrm{Ag}+\mathrm{Au}$ & $1: 3$ ratio & Enhanced TFC. & [49] \\
\hline
\end{tabular}

MS: Murashige and Skoog Basal Medium; BA: 6-Benzylaminopurine; NAA: 1-Naphthaleneacetic acid; TFC: total flavonoid content; DW: dry weight.

The addition of different NPs in combination is also effective in inducing stress in plants. To test this hypothesis, different ratios of AgNPs and gold NPs (AuNPs) alone or in combination with naphthalene acetic acid (NAA) were investigated for callus culture development and the production of phenolics and flavonoid compounds in Prunella vulgaris. As a consequence, the Ag-AuNPs (1:3) in combination with NAA induced maximum accumulation of flavonoid (6.71 mg/g-DW) content [48]. Likewise, enhanced flavonoids (7.62 mg/g-DW) were produced in P. vulgaris cell suspension culture [49].

\subsection{CuNPs and CuONPs as a Novel Elicitor of Flavonoids}

CuNPs possess unique physical resistance, electrical conductivity and chemical reactivity linked to their small size and high specific surface area [50]. The foliar spray of CuNPs in different concentrations $\left(50,125,250,500 \mathrm{mg} \cdot \mathrm{L}^{-1}\right)$ on tomato showed an increase in flavonoid contents in tomato fruit. The highest content of flavonoids in the tomato fruits was obtained with the application of $50 \mathrm{mg} \cdot \mathrm{L}^{-1}$ of CuNPs, exceeding the control by $36.14 \%$. This suggests that low doses of CuNPs generate metabolic effects due to the $\mathrm{Cu}$ accumulation and ROS generation [51]. Ocimum basilicum or basil is an important medic- 
inal herb cultivated around the world which is enriched with bioactive compounds. A comparative study suggested the elevated regeneration capacity of basil plant via somatic embryogenesis using CuNPs as compared to copper sulfate solution [52]. Moreover, copper sulfate NPs ( $\left.\mathrm{CuSO}_{4} \mathrm{NPs}\right)$ enhanced the flavonoid content in O. basilicum seeds [53].

$\mathrm{CuONPs}$ are also reported to elicit in vitro cultures for enhanced flavonoid production (Table 2). Nano-CuO stress on Srian Barley (Hordeum vulgare) leaves exhibited a significantly increased flavonol level ( 1.2-fold over the control) on day 20 after 20 days; however, chlorophyll content decreased significantly [54]. CuONPs upregulated the transcription of genes associated with oxidative stress, therefore enhancing the phytochemical profile of $B$. rapa seedlings [55]. The cell suspension culture of Gymnema sylvestre when elicited with CuONPs $(25-55 \mathrm{~nm})$ resulted in a 2-fold increase in TPC and TFC [56]. Similarly, a higher TFC (9.450 and $12.878 \mathrm{mg} \mathrm{QE} \mathrm{g}^{-1}$ extract) in the shoots and roots of Cichorium intybus was observed upon nano-elicitation with CuONPs 20 days after treatment [57]. The highest flavonoid content, $23.076 \pm 5.128 \mathrm{mg} \mathrm{QE} / \mathrm{g}$ extract, was observed in the roots of CuONP elicited Withania somnifera plant 20 days after treatment [58].

The influence of CuONPs and polyvinyl pyrrolidone (PVP) and polyethylene glycol (PEG) impregnated CuONPs on seed germination, callus induction and the production of secondary metabolites in the shoots and roots of Trigonella foenum-graecum was studied in a comparative manner. It was found that PVP and PEG impregnated CuONPs were less toxic for calli induction. Furthermore, secondary metabolism was also enhanced as a result of nano-elicitation in a concentration dependent manner [59]. Despite the enhancement in bioactive compounds, a negative impact of nano-elicitation on biomass has also been reported. The influence of CuONPs on A. thaliana seedlings showed a significant reduction in plant biomass and total chlorophyll content, while anthocyanin content enhanced in response to all concentrations [60].

Stevia rebaudiana, called candy leaf, is a perennial herb which naturally protects from diabetes mellitus, hypertension and obesity [61]. Callus culture of $S$. rebaudiana was treated with $\mathrm{CuONPs}$ and ZnONPs in various concentrations. Phytochemical analysis revealed the highest TFC $(2.23 \mu \mathrm{g} / \mathrm{mg}$ of DW) in response to $100 \mathrm{mg} / \mathrm{L} \mathrm{CuONPs}$, while the highest TFC $(2.85 \mu \mathrm{g} / \mathrm{mg}$ of DW) was recorded for $100 \mathrm{mg} / \mathrm{L} \mathrm{ZnONPs}$. The lowest TFC was recorded in response to a $500 \mathrm{mg} / \mathrm{L}$ concentration of CuONPs as well as ZnONPs. Moreover, zero TFC was recorded when elicited with $1000 \mathrm{mg} / \mathrm{L}$ of both types of NPs. This trend suggests that stress increases by increasing the concentration of CuONPs or ZnONPs due to the formation of reactive oxygen species and enhanced secondary metabolism. However, after reaching a certain threshold, different physiological parameters of callus and the production of antioxidants begin to decline [62].

Bimetallic $\mathrm{Cu}$-AuNPs were reported to enhance total flavonoid production (TFP$29.5 \mathrm{mg} / \mathrm{L}$ ) in submerged root cultures of S. rebaudiana [63].

\subsection{ZnONPs as a Novel Elicitor of Flavonoids}

ZnONPs have also been investigated as abiotic elicitors of plant secondary metabolites (Table 3). Not only size, but also the morphology of NPs plays a role in effective elicitation. Licorice (Glycyrrhiza glabra) roots and rhizomes contain more than 100 various useful compounds, including phenolic compounds and glycyrrhizin [64]. In a study, the effects of bulk and nano sized $\mathrm{ZnO}$ and $\mathrm{CuO}$ on some secondary metabolites were compared in G. glabra seedlings. Generally, both bulk and nano-sized particles enhanced the secondary metabolism in comparison to the control. It was observed that nano-sized $\mathrm{ZnONPs}$ were efficient in eliciting the anthocyanin content compared to bulk sized $\mathrm{ZnO}$ and the control [65]. Due to their nanometer-size, NPs can easily penetrate plant cell walls and plasma membranes as well as the cytoplasm and cell organelles, therefore affecting the plant metabolism effectively [66]. 
Table 2. Copper NPs (CuNPs) and copper oxide NPs (CuONPs) as elicitors of flavonoids.

\begin{tabular}{|c|c|c|c|c|c|c|c|}
\hline Plant Species & $\begin{array}{l}\text { Type of In } \\
\text { Vitro Culture }\end{array}$ & $\begin{array}{l}\text { Growth } \\
\text { Media }\end{array}$ & NP Type & $\begin{array}{l}\text { NP Size } \\
(\mathrm{nm})\end{array}$ & $\begin{array}{c}\text { Effective } \\
\text { Concentration } \\
\text { of NPs }\end{array}$ & $\begin{array}{l}\text { Effect on Flavonoid } \\
\text { Production }\end{array}$ & References \\
\hline S. lycopersicum & Plantlets & Greenhouse & $\mathrm{Cu}$ & 50 & $50 \mathrm{mg} / \mathrm{L}$ & 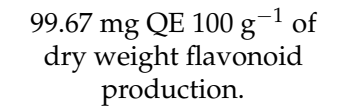 & [51] \\
\hline O. basilicum & Seeds & MS media & $\mathrm{CuSO} 4$ & - & $10 \mu \mathrm{M} / \mathrm{L}$ & $\begin{array}{l}\text { Enhanced total flavonoid } \\
\text { production. }\end{array}$ & [53] \\
\hline H. vulgare & Seedlings & MS media & $\mathrm{CuO}$ & $<50$ & $\begin{array}{c}0.5 \mathrm{mM}, 1 \mathrm{mM} \\
\text { and } 1.5 \mathrm{mM}\end{array}$ & $\begin{array}{l}\text { Enhanced flavonol } \\
\text { production on day } 20 .\end{array}$ & [54] \\
\hline G. sylvestre & $\begin{array}{l}\text { Cell } \\
\text { suspension } \\
\text { culture }\end{array}$ & MS media & $\mathrm{CuO}$ & $25-55$ & $3 \mathrm{mg} / \mathrm{L}$ & TFC enhanced 2-fold. & [56] \\
\hline C. intybus & $\begin{array}{l}\text { Shoots and } \\
\text { roots }\end{array}$ & MS media & $\mathrm{CuO}$ & - & $1 \mathrm{ppm}$ & $\begin{array}{l}\text { Highest } 9.450 \text { and } \\
12.878 \mathrm{mg} \mathrm{QE} \mathrm{g}^{-1} \text { extract } \\
\text { TFC level in shoots and } \\
\text { roots, respectively. }\end{array}$ & [57] \\
\hline W. somnifera & $\begin{array}{l}\text { Shoots and } \\
\text { roots }\end{array}$ & MS media & $\mathrm{CuO}$ & - & $1 \mathrm{ppm}$ & TFC production increased. & [58] \\
\hline $\begin{array}{c}T . \\
\text { foenumgraecum }\end{array}$ & Callus culture & MS media & $\begin{array}{l}\text { CuO, PVP } \\
\text { and PEG } \\
\text { impreg- } \\
\text { nated }\end{array}$ & 47 & $5 \mathrm{mg} / \mathrm{L}$ & $\begin{array}{l}\text { Flavonoid production } \\
\text { enhanced. }\end{array}$ & [59] \\
\hline A. thaliana & Seedlings & MS media & $\mathrm{CuO}$ & - & $10-100 \mathrm{mg} / \mathrm{L}$ & $\begin{array}{l}\text { Enhanced anthocyanin } \\
\text { content. }\end{array}$ & [60] \\
\hline S. rebaudiana & Callus & MS media & $\mathrm{CuOZnO}$ & - & $\begin{array}{l}100 \mathrm{mg} / \mathrm{L} \\
100 \mathrm{mg} / \mathrm{L}\end{array}$ & $\begin{array}{c}\text { Highest } 2.23 \mu \mathrm{g} / \mathrm{mg} \text { of } \\
\text { DW TFC } \\
\text { Highest } 2.85 \mu \mathrm{g} / \mathrm{mg} \text { of } \\
\text { DW TFC }\end{array}$ & [62] \\
\hline $\begin{array}{l}\text { S. rebaudiana } \\
\text { Bertoni }\end{array}$ & $\begin{array}{l}\text { Submerged } \\
\text { root culture }\end{array}$ & $\begin{array}{l}\text { MS media with } \\
\text { NAA }\end{array}$ & $\begin{array}{c}\mathrm{Cu}-\mathrm{Au} \\
\text { bimetallic }\end{array}$ & - & - & TFC increased. & [63] \\
\hline
\end{tabular}

MS: Murashige and Skoog Basal Medium; NAA: 1-Naphthaleneacetic acid; TFC: total flavonoid content; PVP: polyvinyl pyrrolidone; PEG: polyethylene glycol; QE: quercetin equivalent; DW: dry weight.

Table 3. Zinc oxide NPs (ZnONPs) as an elicitor of flavonoids.

\begin{tabular}{|c|c|c|c|c|c|c|}
\hline Plant Species & $\begin{array}{l}\text { Type of In Vitro } \\
\text { Culture }\end{array}$ & Growth Media & $\begin{array}{l}\text { NP Size } \\
(\mathbf{n m})\end{array}$ & $\begin{array}{c}\text { Effective } \\
\text { Concentration } \\
\text { of NPs }\end{array}$ & Effect on Flavonoid Production & References \\
\hline G. glabra & Seedlings & $\begin{array}{l}\text { Hoagland's } \\
\text { solution }\end{array}$ & - & $\begin{array}{l}1 \mu \mathrm{M} \\
1 \mu \mathrm{M}\end{array}$ & $\begin{array}{l}\text { Both } \mathrm{CuO} \text { and } \mathrm{ZnO} \text { enhanced } \\
\text { the production of tannins, } \\
\text { anthocyanins, phenolics, } \\
\text { flavonoids and glycyrrhizin. }\end{array}$ & [65] \\
\hline E. purpurea & Callus & MS media & - & $75 \mathrm{mg} / \mathrm{L}$ & Flavonoid production enhanced. & [67] \\
\hline L. usitatissimum & Cell suspension & MS media & 35 & $1-500 \mu \mathrm{g} / \mathrm{L}$ & $\begin{array}{l}123.83 \text { mg/L highest TFC } \\
\text { recorded. }\end{array}$ & [68] \\
\hline Stevia rebaudiana & Shoot & MS media & 34 & $1.0 \mathrm{mg} / \mathrm{L}$ & Increase in TFC. & [69] \\
\hline L. ledebourii & Shoot & MS media & - & $20-100 \mathrm{mg} / \mathrm{L}$ & $\begin{array}{l}\text { Anthocyanin, phenolics and } \\
\text { flavonoid production increased. }\end{array}$ & [70] \\
\hline S. tuberosum & Plant & Potting soil & - & 300,500 ppm & $\begin{array}{l}\text { Increase in anthocyanin and } \\
\text { flavonoid content. }\end{array}$ & [71] \\
\hline S. rebaudiana & Plant & Nutrient solution & - & $75 \mathrm{mg} / \mathrm{L}$ & $87.8 \%$ flavonoid production. & [72] \\
\hline S. rebaudiana & Root culture & MS media & $\begin{array}{l}\mathrm{ZnO} 20-30 \\
\mathrm{CuO} 25-30\end{array}$ & - & $\begin{array}{l}\text { TFC level enhanced when } \\
\text { treated with } 2 \mathrm{mg} / \mathrm{L} \text { ZnONPs } \\
\text { and } 20 \mathrm{mg} / \mathrm{L} \mathrm{CuONPs.}\end{array}$ & [73] \\
\hline
\end{tabular}

MS: Murashige and Skoog Basal Medium; TFC: total flavonoid content.

Seventy-five milligrams per liter of biogenic $\mathrm{ZnONPs}$ was reported to produce $3.7 \mathrm{mg} / \mathrm{g}$ DW flavonoids as compared to commercially available micro-sized $\mathrm{ZnO}$, which produced $3.01 \mathrm{mg} / \mathrm{g}$ DW flavonoids in callus culture of Echinacea purpurea [67]. Biogenic ZnONPs effectively elicited in vitro flavonoid production in a cell suspension culture of Flax [68]. The shoot culture of $S$. rebaudiana and Lilium ledebourii showed increased secondary metabolism and TFC in response to engineered ZnONP elicitation [69,70]. 
ZnONPs enhanced anthocyanin and flavonoid contents in potato plants at an effective concentration of 300-500 ppm; however, an increase in enzymatic and non-enzymatic antioxidants led to oxidative stress and toxicity to potato plants [71]. There was $87.8 \%$ flavonoid production in S. rebaudiana plants when stressed with plant-synthesized ZnONPs [72]. The physiological and metabolic responses of candy leaf were elicited as a defense against applied ZnONPs and CuONPs [73].

\subsection{Various Metallic Oxide NPs as an Elicitor of Flavonoids}

There are various other metallic oxide NPs reported as elicitors of flavonoids (Table 4). The effects of thidiazuron (TDZ) growth regulator and magnesium oxide NPs (MgONPs) on radish seeds under lead stress were evaluated. There was a significant increase in plant growth, phenolic and flavonoid contents, free radical scavenging activity, and lead phytoaccumulation in response to combined TDZ and MgONP treatment. Moreover, there was a positive correlation of flavonoids with dry biomass and lead accumulation $[69,74]$. Nickle oxide NPs (NiONPs), $\mathrm{CuO}$ and $\mathrm{ZnO}$ significantly enhanced anthocyanins, TPC and TFC in in vitro grown eggplant seeds in a dose-dependent manner [75].

Dracocephalum kotschyi is a valuable source of rosmarinic acid and methoxylated hydroxyflavones which shows antioxidative and antiproliferative potential against various cancer cells [76]. The application of $\mathrm{Fe}_{3} \mathrm{O}_{4} \mathrm{NPs}$ induced secondary metabolic gene expression as well as enhanced flavonoid content in a hairy root culture of D. kotschyi [77]. $\mathrm{Fe}_{3} \mathrm{O}_{4} \mathrm{NPs}$ led to a superior TFC (4.65 $\left.\mathrm{mg} \mathrm{g}^{-1} \mathrm{DW}\right)$ in the hairy roots of chicory [78]. Iron NPs (FeNPs) showed growth promoting effects on in vitro grown $S$. rebaudiana at lower concentrations $(45 \mu \mathrm{g} / \mathrm{L})$. However, higher doses (90 and $135 \mu \mathrm{g} / \mathrm{L}$ ) of FeNPs were found detrimental to growth characteristics and development. Moreover, a higher concentration of FeNPs $(135 \mu \mathrm{g} / \mathrm{L})$ induced stress, which produced a higher TFC [79]. Recently, magnetic $\mathrm{Fe}_{2} \mathrm{O}_{3} \mathrm{NPs}$ in the presence of a static magnetic field (SMF) resulted in the enhanced production of rosmarinic acid, naringin, apigenin, thymol, carvacrol, quercetin and rutin, TPC, TFC, anthocyanins, lignin and malondialdehyde in a cell suspension culture of $D$. polychaetum [80]. The use of magnetic fields has recently been proposed for plant growth and the production of plant secondary metabolites since they are less hazardous for the environment [81].

The role of cerium oxide NPs $\left(\mathrm{CeO}_{2} \mathrm{NPs}\right)$ on food quality is not well known yet. Therefore, the impact of $\mathrm{CeO}_{2} \mathrm{NPs}$ on the secondary metabolism of $R$. sativus seed was analyzed. The results were not as promising, as NPs increased the level of antioxidant compounds and showed no effect on TPC and TFC [82]. Nigella arvensis was treated with different concentrations of $\mathrm{Al}_{2} \mathrm{O}_{3} \mathrm{NPs}, \mathrm{NiONPs}$, and $\mathrm{TiO}_{2} \mathrm{NPs}$ for 21 days. A significant increase in TFC and TPC was found. Moreover, the maximum content of quercetin was observed in the shoot and root parts under $50 \mathrm{mg} / \mathrm{L} \mathrm{NiONPs}$ with a 2.2- and 1.8-fold increase compared to the control group. However, the kaempferol content was significantly decreased in all treatments, except for $1000 \mathrm{mg} / \mathrm{L} \mathrm{NiONP}$ treatment in the root parts, which was 2.9-fold higher than the control group. These findings suggest the potential use of $\mathrm{NPs}$ as elicitors, considering their effective concentration [83]. $\mathrm{TiO}_{2} \mathrm{NPs}_{\mathrm{s}}$ have also been reported to enhance phenolic and flavonoid content in embryogenic callus culture of Cicer arietinum [84].

The stimulation of D. kotschyi hairy roots by silicon dioxide $\mathrm{NPs}\left(\mathrm{SiO}_{2} \mathrm{NPs}\right)$ led to a significant increase in the induction and production of important pharmaceutical compounds including anticancer flavonoids, including cirsimaritin, xanthomicrol and isokaempferide [85]. $\mathrm{SiO}_{2} \mathrm{NPs}$ also elicited in vitro hairy root cultures of $\mathrm{H}$. reticulatus and H. pusillus [86]. Manganese oxide NPs $\left(\mathrm{Mn}_{2} \mathrm{O}_{3} \mathrm{NPs}\right)$ at a lower concentration promoted plantlet growth and enhanced the biosynthesis of the regulation of pharmacologically active metabolites by the activation of specific antioxidant enzymes. However, at higher concentrations (50-200 mg/L), $\mathrm{Mn}_{2} \mathrm{O}_{3} \mathrm{NPs}$ exhibited oxidative stress and toxicity in an in vitro plant culture of deadly nightshade [87]. 
Table 4. Various metallic oxide NPs as elicitors of flavonoids.

\begin{tabular}{|c|c|c|c|c|c|c|c|}
\hline Plant Species & $\begin{array}{l}\text { Type of In Vitro } \\
\text { Culture }\end{array}$ & $\begin{array}{l}\text { Growth } \\
\text { Media }\end{array}$ & NP Type & $\begin{array}{l}\text { NP Size } \\
(\mathrm{nm})\end{array}$ & $\begin{array}{c}\text { Effective } \\
\text { Concentration } \\
\text { of NPs }\end{array}$ & Effect on Flavonoid Production & References \\
\hline R. sativus & Seed & MS media & $\mathrm{MgO}$ & - & $20 \mathrm{mg} / \mathrm{L}$ & $\begin{array}{l}\text { Increased plant biomass, TFC } \\
\text { and antioxidant activity. }\end{array}$ & [74] \\
\hline S. melongena & Seed & Filter paper & $\begin{array}{l}\mathrm{ZnO} \\
\mathrm{NiO} \\
\mathrm{CuO}\end{array}$ & $\begin{array}{l}18-20 \\
10-20 \\
25-55\end{array}$ & $100-1000 \mathrm{mg} / \mathrm{L}$ & Anthocyanin, TFC enhanced. & [75] \\
\hline D. kotschyi & Hairy root & MS media & $\mathrm{Fe}_{2} \mathrm{O}_{3}$ & - & $75 \mathrm{mg} / \mathrm{L}$ & Enhanced flavonoid production. & [77] \\
\hline C. intybus & Hairy root & MS media & $\begin{array}{c}\mathrm{Fe}_{3} \mathrm{O}_{4} \\
\mathrm{ZnO}\end{array}$ & - & $\begin{array}{l}50 \mathrm{mg} / \mathrm{L} \\
50 \mathrm{mg} / \mathrm{L}\end{array}$ & $\begin{array}{l}\text { TFC increased in response to } \\
\mathrm{Fe}_{3} \mathrm{O}_{4} \mathrm{NPs} \text { only. }\end{array}$ & [78] \\
\hline S. rebaudiana & $\begin{array}{l}\text { Micro- } \\
\text { propagation }\end{array}$ & $\begin{array}{l}\text { MS media } \\
\text { supplemented } \\
\text { with sucrose } \\
(3 \%) \text { and BA }\end{array}$ & $\mathrm{Fe}$ & $<50$ & $135 \mu \mathrm{g} / \mathrm{L}$ & TFC level was $1.6 \mathrm{mg} / \mathrm{g}$ DW. & [79] \\
\hline D. polychaetum & Cell suspension & Potting mix & $\begin{array}{l}\mathrm{SMF} \\
\mathrm{Fe}_{2} \mathrm{O}_{3}\end{array}$ & 8 & $250 \mathrm{mg} / \mathrm{kg}$ & $\begin{array}{l}\text { Naringin, rosmarinic acid, } \\
\text { carvacrol, apigenin, quercetin, } \\
\text { thymol, rutin, TPC, TFC, lignin, } \\
\text { anthocyanins and } \\
\text { malondialdehyde production } \\
\text { increased compared to control. } \\
\text { Increase in antioxidant } \\
\text { compounds and no effect on } \\
\text { TFC. }\end{array}$ & [82] \\
\hline N. arvensis & Seed & $\begin{array}{l}\text { Hoagland's } \\
\text { solution }\end{array}$ & $\begin{array}{l}\mathrm{Al}_{2} \mathrm{O}_{3}, \mathrm{NiO}, \\
\mathrm{TiO}_{2}\end{array}$ & $\begin{array}{c}5 \\
5-8 \\
20\end{array}$ & $0-2500 \mathrm{mg} / \mathrm{L}$ & $\begin{array}{l}\text { TFC, glaucine, quercetin and } \\
\text { kaempferol content increased. }\end{array}$ & [83] \\
\hline C. arietinum & Embryonic callus & MS media & $\mathrm{TiO}_{2}$ & - & $6 \mathrm{mg} / \mathrm{L}$ & $\begin{array}{l}\text { Flavonoid and phenolic content } \\
\text { increased. }\end{array}$ & [84] \\
\hline D. kotschyi & Hairy root & MS Media & $\mathrm{SiO}_{2}$ & 100 & - & $\begin{array}{l}\text { Rosmarinic acid, cirsimaritin, } \\
\text { isokaempferide and } \\
\text { xanthomicrol production } \\
\text { increased 2-fold. }\end{array}$ & [85] \\
\hline $\begin{array}{l}\text { H. reticulatus and } \\
\text { H. pusillus }\end{array}$ & Hairy root & MS media & $\mathrm{SiO}_{2}$ & $10-100$ & $50 \mathrm{mg} / \mathrm{L}$ & $\begin{array}{l}\text { Highest TFC } 4.06 \mathrm{mg} \text { GAE} / \mathrm{g} \\
\text { FW on } 24 \text { hexposure. } \\
4.49 \text {-fold higher flavonoid }\end{array}$ & [86] \\
\hline Atropa belladonna & Plant culture & MS media & $\mathrm{Mn}_{2} \mathrm{O}_{3}$ & 30 & $100 \mathrm{mg} / \mathrm{L}$ & $\begin{array}{l}\text { production than negative } \\
\text { control. }\end{array}$ & [87] \\
\hline
\end{tabular}

MS: Murashige and Skoog Basal Medium; BA: 6-Benzylaminopurine; TFC: total flavonoid content; DW: dry weight; FW: fresh weight; GAE: gallic acid equivalent.

\subsection{Carbon-Based Nanomaterials as an Elicitor of Flavonoids}

The most commonly employed carbon nanomaterials include single-walled carbon nanotubes (SWCNTs), multi-walled carbon nanotubes (MWCNTs), fullerenes and chitosanNPs (Table 5). The discovery of MWCNTs, with their nearly perfect cylindrical structure of seamless graphite, together with the equally remarkable high aspect ratio SWCNTs, has led to an intense interest in these remarkable structures [88]. The in vitro callus culture of Satureja khuzestanica was elicited with different concentrations of MWCNTs $(0-500 \mu \mathrm{g} / \mathrm{mL})$. At lower concentrations (25 and $50 \mu \mathrm{g} / \mathrm{mL}$ ) of MWCNTs, maximal callus growth and biomass accumulated, while at higher concentrations (100 and $250 \mu \mathrm{g} / \mathrm{mL})$, the maximum level of secondary metabolites accumulated. Maximum flavonoids (21.48 mg CE/g DW) accumulated at $100 \mu \mathrm{g} / \mathrm{mL}$ MWCNT concentration [89]. MWCNTs enhanced the TPC, TFC, rosmarinic acid, antioxidants and PAL activity in seedlings of $S$. verticillata and Thymus daenensis $[90,91]$. A group of researchers reported that SWCNTs resulted in a higher production of flavonoids (20.66 mg QE/g DW) in plantlets of Simmondsia chinensis than the control [92].

Chitosan is a modified biopolymer, derived by the partial deacetylation of chitin, which acts as a defense elicitor [93]. Chitosan has been reported to activate pathogenesis genes and plant metabolism-related genes [94]. Chitosan-NPs increased the accumulation of phenolics and flavonoids by $20 \%$ and $24 \%$, respectively, in shoot culture of Camellia sinensis [95]. 
Table 5. Carbon-based nanomaterials as elicitors of flavonoids.

\begin{tabular}{|c|c|c|c|c|c|c|c|}
\hline Plant Species & $\begin{array}{l}\text { Type of In } \\
\text { Vitro Culture }\end{array}$ & $\begin{array}{l}\text { Growth } \\
\text { Media }\end{array}$ & NP Type & $\begin{array}{l}\text { NP Size } \\
(\text { (nm) }\end{array}$ & $\begin{array}{c}\text { Effective } \\
\text { Concentration } \\
\text { of NPs }\end{array}$ & $\begin{array}{l}\text { Effect on Flavonoid } \\
\text { Production }\end{array}$ & References \\
\hline S. khuzestanica & Callus & B5 basal & MWCNTs & - & $100 \mu \mathrm{g} / \mathrm{mL}$ & $\begin{array}{l}\text { 2.6-fold higher TFC than } \\
\text { control. }\end{array}$ & [89] \\
\hline T. daenensis & Seedlings & MS media & MWCNTs & $50 \mu \mathrm{m}$ & $0-2000 \mu \mathrm{g} / \mathrm{mL}$ & $\begin{array}{l}\text { Increased TFC, } \\
\text { antioxidant and PAL } \\
\text { activity }\end{array}$ & [90] \\
\hline $\begin{array}{c}\text { Salvia } \\
\text { verticillata }\end{array}$ & Seedlings & Potting mix & MWCNTs & - & 0-1000 mg/L & $\begin{array}{l}\text { Secondary metabolism } \\
\text { enhanced. }\end{array}$ & [91] \\
\hline S. chinensis & Plantlets & MS media & SWCNTs & $110-170$ & $0.002 \mathrm{~g} / \mathrm{L}$ & $\begin{array}{l}\text { Flavonoid contents were } \\
\text { increased. }\end{array}$ & [92] \\
\hline $\begin{array}{l}\text { Camellia } \\
\text { sinensis }\end{array}$ & $\begin{array}{l}\text { Foliar spray on } \\
\text { leaves }\end{array}$ & Hydroponic & $\begin{array}{l}\text { Chitosan- } \\
\text { NPs }\end{array}$ & 40-180 & 0.01 & $\begin{array}{l}\text { Increase in phenolic and } \\
\text { flavonoid accumulation. }\end{array}$ & [95] \\
\hline
\end{tabular}

MWCNTs: multi-walled carbon nanotubes; SWCNTs: single-walled carbon nanotubes (SWCNTs), MS: Murashige and Skoog basal medium; B5: Gamborg B5 basal medium; TFC: total flavonoid content; PAL: L-phenylalanine ammonialyse.

\section{Conclusions and Future Perspectives}

Elicitation is a promising strategy to over-produce industrially important flavonoids. Amongst different types of elicitors, NPs as elicitors are effective in lower concentrations to enhance the productivity of flavonoids. Despite immense research on NPs as novel elicitors of flavonoids, there are still some knowledge gaps which need to be filled. Firstly, a deep understanding of the underlying mechanism of nano-elicitation is important for its successful industrial adoption. Moreover, an understanding of plant response to the nanomaterials applied as elicitors either individually or in combination with other classes of NPs or with other types of elicitors is essential for developing strategies for enhanced flavonoid production [31].

Negative effects on plant primary metabolism such as lower chlorophyll content, a decrease in cell viability, a decrease in sugar concentration and suppressed seed germination have been reported during nano-elicitation experiments [25]. To ensure the success of elicitation, addressing nano-toxicity in plants is important. Furthermore, the targeted delivery of NPs enhances the efficacy of elicitation using lower concentration of NPs and prevents phyto-toxicity. This can be achieved by the surface functionalization of NPs with bio-molecules, tags or magnetic fields [96].

Moreover, in most of the studies, an enhancement in the production of flavonoids is reported only in terms of total flavonoid content. This gives an overall picture of NPs' role as an elicitor of flavonoids. However, from an industrial viewpoint it is important to characterize and report the effect of NPs on specific industrially important flavonoids. There are some plant species naturally enriched with flavonoids, such as Allium species, which have not been treated with NPs to elicit flavonoid production [97]. Further analysis of different plant species will allow the discovery of novel flavonoids which can be nanoelicited in in vitro cultures for the enhanced production of flavonoids for industrial use.

Author Contributions: Conceptualization, writing and editing, A.K.K., S.K., D.T., C.H., B.H.A. and S.A. All authors have read and agreed to the published version of the manuscript.

Funding: This research received no external funding.

Institutional Review Board Statement: Not applicable.

Informed Consent Statement: Not applicable.

Data Availability Statement: The data presented in this study are available on request from the corresponding author.

Acknowledgments: B.H.A. and C.H. acknowledge the research fellowship and Research Consortium from Le Studium-Institute for Advanced Studies, Loire Valley, Orléans, France. C.H. and B.H.A. gratefully acknowledge the support of Campus France through the PHC PERIDOT. C.H. and D.T. gratefully acknowledge the support of Campus France through the PHC SIAM (PNPIA, Project 
44926WK). D.T. gratefully acknowledges the support of the French government via the French Embassy in Thailand in the form of Junior Research Fellowship Program 2018.

Conflicts of Interest: The authors declare no conflict of interest.

\section{References}

1. Cheng, K.; Wang, K.; Fang, X.; Yang, J.; Yao, Y.; Nandakumar, K.S.; Salem, M. Recent Research on Flavonoids and their Biomedical applications. Curr. Med. Chem. 2020, 27, 1-25. [CrossRef]

2. Mathesius, U. Flavonoid Functions in Plants and Their Interactions with Other Organisms. Plants 2018, 7, 30. [CrossRef] [PubMed]

3. Panche, A.N.; Diwan, A.D.; Chandra, S.R. Flavonoids: An overview. J. Nutr. Sci. 2016, 5, e47. [CrossRef]

4. Gugliandolo, E.; Fusco, R.; D’Amico, R.; Peditto, M.; Oteri, G.; Di Paola, R.; Cuzzocrea, S.; Navarra, M. Treatment with a flavonoid-rich fraction of bergamot juice improved lipopolysaccharide-induced periodontitis in rats. Front. Pharmacol. 2019, 9, 1563. [CrossRef] [PubMed]

5. Hano, C.; Tungmunnithum, D. Plant Polyphenols, more than Just Simple Natural Antioxidants: Oxidative Stress, Aging and Age-Related Diseases. Medicines 2020, 7, 26. [CrossRef]

6. Nazir, M.; Tungmunnithum, D.; Bose, S.; Drouet, S.; Garros, L.; Giglioli-Guivarc'h, N.; Abbasi, B.H.; Hano, C. Differential Production of Phenylpropanoid Metabolites in Callus Cultures of Ocimum basilicum L. with Distinct In Vitro Antioxidant Activities and In Vivo Protective Effects against UV stress. J. Agric. Food Chem. 2019, 67, 1847-1859. [CrossRef] [PubMed]

7. Tungmunnithum, D.; Drouet, S.; Kabra, A.; Hano, C. Enrichment in Antioxidant Flavonoids of Stamen Extracts from Nymphaea lotus L. Using Ultrasonic-Assisted Extraction and Macroporous Resin Adsorption. Antioxidants 2020, 9, 576. [CrossRef]

8. Drouet, S.; Leclerc, E.A.; Garros, L.; Tungmunnithum, D.; Kabra, A.; Abbasi, B.H.; Lainé, É.; Hano, C. A Green UltrasoundAssisted Extraction Optimization of the Natural Antioxidant and Anti-Aging Flavonolignans from Milk Thistle Silybum marianum (L.) Gaertn. Fruits for Cosmetic Applications. Antioxidants 2019, 8, 304. [CrossRef]

9. Anna Malinowska, M.; Billet, K.; Drouet, S.; Munsch, T.; Unlubayir, M.; Tungmunnithum, D.; Giglioli-Guivarc'h, N.; Hano, C.; Lanoue, A. Grape Cane Extracts as Multifunctional Rejuvenating Cosmetic Ingredient: Evaluation of Sirtuin Activity, Tyrosinase Inhibition and Bioavailability Potential. Molecules 2020, 25, 2203. [CrossRef] [PubMed]

10. Kumar, S.; Pandey, A.K. Chemistry and Biological Activities of Flavonoids: An Overview. Sci. World J. 2013, $2013,162750$. [CrossRef]

11. Goossens, A.; Häkkinen, S.T.; Laakso, I.; Seppänen-Laakso, T.; Biondi, S.; De Sutter, V.; Lammertyn, F.; Nuutila, A.M.; Söderlund, H.; Zabeau, M.; et al. A functional genomics approach toward the understanding of secondary metabolism in plant cells. Proc. Natl. Acad. Sci. USA 2003, 100, 8595-8600. [CrossRef]

12. Erb, M.; Kliebenstein, D.J. Plant Secondary Metabolites as Defenses, Regulators, and Primary Metabolites: The Blurred Functional Trichotomy. Plant Physiol. 2020, 184, 39-52. [CrossRef] [PubMed]

13. Havsteen, B.H. The biochemistry and medical significance of the flavonoids. Pharmacol. Ther. 2002, 96, 67-202. [CrossRef]

14. Falcone Ferreyra, M.L.; Rius, S.; Casati, P. Flavonoids: Biosynthesis, biological functions, and biotechnological applications. Front. Plant Sci. 2012, 3, 222. [CrossRef]

15. Mierziak, J.; Kostyn, K.; Kulma, A. Flavonoids as important molecules of plant interactions with the environment. Molecules 2014, 19, 16240-16265. [CrossRef]

16. Marais, J.P.J.; Deavours, B.; Dixon, R.A.; Ferreira, D. The Stereochemistry of Flavonoids. In The Science of Flavonoids; Grotewold, E., Ed.; Springer: New York, NY, USA, 2006; pp. 1-46. [CrossRef]

17. Alzand, K. Flavonoids: Chemistry, Biochemistry and Antioxidant activity. J. Pharm. Res. 2012, 5, 4013-4020.

18. Rates, S.M.K. Plants as source of drugs. Toxicon 2001, 39, 603-613. [CrossRef]

19. Park, J.-S.; Seong, Z.-K.; Kim, M.-S.; Ha, J.-H.; Moon, K.-B.; Lee, H.-J.; Lee, H.-K.; Jeon, J.-H.; Park, S.U.; Kim, H.-S. Production of Flavonoids in Callus Cultures of Sophora flavescens Aiton. Plants 2020, 9, 688. [CrossRef] [PubMed]

20. Bharati, A. In vitro production of flavonoids: A review. World J. Pharm. Pharm. Sci. 2014, 3, 508-533.

21. Yin, Y.-C.; Hou, J.-M.; Tian, S.-K.; Yang, L.; Zhang, Z.-X.; Li, W.-D.; Liu, Y. Overexpressing chalcone synthase (CHS) gene enhanced flavonoids accumulation in Glycyrrhiza uralensis hairy roots. Bot. Lett. 2020, 167, 219-231. [CrossRef]

22. Marchev, A.S.; Yordanova, Z.P.; Georgiev, M.I. Green (cell) factories for advanced production of plant secondary metabolites. Crit. Rev. Biotechnol. 2020, 40, 443-458. [CrossRef]

23. Narayani, M.; Srivastava, S. Elicitation: A stimulation of stress in in vitro plant cell/tissue cultures for enhancement of secondary metabolite production. Phytochem. Rev. 2017, 16, 1227-1252. [CrossRef]

24. Roy, A.; Bharadvaja, N. Establishment of root suspension culture of Plumbago zeylanica and enhanced production of plumbagin. Ind. Crops. Prod. 2019, 137, 419-427. [CrossRef]

25. Anjum, S.; Anjum, I.; Hano, C.; Kousar, S. Advances in nanomaterials as novel elicitors of pharmacologically active plant specialized metabolites: Current status and future outlooks. RSC Adv. 2019, 9, 40404-40423. [CrossRef]

26. Amer, A. Biotechnology approaches for in vitro production of flavonoids. J. Microbiol. Biotechnol. Food Sci. 2019, 2019, 457-468. [CrossRef]

27. Garcia-Brugger, A.; Lamotte, O.; Vandelle, E.; Bourque, S.; Lecourieux, D.; Poinssot, B.; Wendehenne, D.; Pugin, A. Early signaling events induced by elicitors of plant defenses. Mol. Plant Microbe Interact. 2006, 19, 711-724. [CrossRef] [PubMed] 
28. Zhao, J.; Davis, L.C.; Verpoorte, R. Elicitor signal transduction leading to production of plant secondary metabolites. Biotechnol. Adv. 2005, 23, 283-333. [CrossRef]

29. Ramirez-Estrada, K.; Vidal-Limon, H.; Hidalgo, D.; Moyano, E.; Golenioswki, M.; Cusidó, R.M.; Palazon, J. Elicitation, an Effective Strategy for the Biotechnological Production of Bioactive High-Added Value Compounds in Plant Cell Factories. Molecules 2016, 21, 182. [CrossRef]

30. Angelova, Z.; Georgiev, S.; Roos, W. Elicitation of plants. Biotechnol. Biotechnol. Equip. 2006, 20, 72-83. [CrossRef]

31. Baenas, N.; García-Viguera, C.; Moreno, D.A. Elicitation: A tool for enriching the bioactive composition of foods. Molecules 2014, 19, 13541-13563. [CrossRef] [PubMed]

32. Namdeo, A. Plant cell elicitation for production of secondary metabolites: A review. Pharmacogn. Rev. 2007, 1, 69-79.

33. Marslin, G.; Sheeba, C.J.; Franklin, G. Nanoparticles alter secondary metabolism in plants via ROS burst. Front. Plant Sci. 2017, 8 , 832. [CrossRef]

34. Kruszka, D.; Sawikowska, A.; Kamalabai Selvakesavan, R.; Krajewski, P.; Kachlicki, P.; Franklin, G. Silver nanoparticles affect phenolic and phytoalexin composition of Arabidopsis thaliana. Sci. Total Environ. 2020, 716, 135361. [CrossRef]

35. Grover, J.; Yadav, S. Pharmacological actions and potential uses of Momordica charantia: A review. J. Ethnopharmacol. 2004, 93, 123-132. [CrossRef] [PubMed]

36. Chung, I.-M.; Rekha, K.; Rajakumar, G.; Thiruvengadam, M. Elicitation of silver nanoparticles enhanced the secondary metabolites and pharmacological activities in cell suspension cultures of bitter gourd. 3 Biotech 2018, 8, 412. [CrossRef] [PubMed]

37. Zuiter, A.S. Proanthocyanidin: Chemistry and Biology: From Phenolic Compounds to Proanthocyanidins. In Reference Module in Chemistry, Molecular Sciences and Chemical Engineering; Elsevier: Amsterdam, The Netherlands, 2014. [CrossRef]

38. Boots, A.W.; Haenen, G.R.M.M.; Bast, A. Health effects of quercetin: From antioxidant to nutraceutical. Eur. J. Pharmacol. 2008, 585, 325-337. [CrossRef]

39. Chung, I.-M.; Rajakumar, G.; Thiruvengadam, M. Effect of silver nanoparticles on phenolic compounds production and biological activities in hairy root cultures of Cucumis anguria. Acta Biol. Hung. 2018, 69, 97-109. [CrossRef]

40. Chung, I.-M.; Rekha, K.; Rajakumar, G.; Thiruvengadam, M. Influence of silver nanoparticles on the enhancement and transcriptional changes of glucosinolates and phenolic compounds in genetically transformed root cultures of Brassica rapa ssp. rapa. Bioprocess Biosyst. Eng. 2018, 41, 1665-1677. [CrossRef]

41. Azeez, L.; Lateef, A.; Adebisi, S.A. Silver nanoparticles (AgNPs) biosynthesized using pod extract of Cola nitida enhances antioxidant activity and phytochemical composition of Amaranthus caudatus Linn. Appl. Nanosci. 2017, 7, 59-66. [CrossRef]

42. Ali, A.; Mohammad, S.; Khan, M.A.; Raja, N.I.; Arif, M.; Kamil, A.; Mashwani, Z.-U.-R. Silver nanoparticles elicited in vitro callus cultures for accumulation of biomass and secondary metabolites in Caralluma tuberculata. Artif. Cells Nanomed. Biotechnol. 2019, 47, 715-724. [CrossRef]

43. Rauf, A.; Jan, M.; Rehman, W.; Muhammad, N. Phytochemical, phytotoxic and antioxidant profile of Caralluma tuberculata NE Brown. Wudpecker J. Pharm. Pharmocol. 2013, 2, 21-25.

44. Yu, M.; Man, Y.; Lei, R.; Lu, X.; Wang, Y. Metabolomics Study of Flavonoids and Anthocyanin-Related Gene Analysis in Kiwifruit (Actinidia chinensis) and Kiwiberry (Actinidia arguta). Plant Mol. Biol. Report. 2020, 38, 353-369. [CrossRef]

45. Khoo, H.E.; Azlan, A.; Tang, S.T.; Lim, S.M. Anthocyanidins and anthocyanins: Colored pigments as food, pharmaceutical ingredients, and the potential health benefits. Food Nutr. Res. 2017, 61, 1361779. [CrossRef] [PubMed]

46. Syu, Y.-Y.; Hung, J.-H.; Chen, J.-C.; Chuang, H.-W. Impacts of size and shape of silver nanoparticles on Arabidopsis plant growth and gene expression. Plant Physiol. Biochem. 2014, 83, 57-64. [CrossRef]

47. Zahir, A.; Nadeem, M.; Ahmad, W.; Giglioli-Guivarc'h, N.; Hano, C.; Abbasi, B.H. Chemogenic silver nanoparticles enhance lignans and neolignans in cell suspension cultures of Linum usitatissimum L. Plant Cell Tiss. Org. Cult. 2019, 136, 589-596. [CrossRef]

48. Fazal, H.; Abbasi, B.H.; Ahmad, N.; Ali, M. Elicitation of medicinally important antioxidant secondary metabolites with silver and gold nanoparticles in callus cultures of Prunella vulgaris L. Appl. Biochem. Biotechnol. 2016, 180, 1076-1092. [CrossRef] [PubMed]

49. Fazal, H.; Abbasi, B.H.; Ahmad, N.; Ali, M.; Shujait Ali, S.; Khan, A.; Wei, D.-Q. Sustainable production of biomass and industrially important secondary metabolites in cell cultures of selfheal (Prunella vulgaris L.) elicited by silver and gold nanoparticles. Artif. Cells Nanomed. Biotechnol. 2019, 47, 2553-2561. [CrossRef] [PubMed]

50. Hong, J.; Rico, C.M.; Zhao, L.; Adeleye, A.S.; Keller, A.A.; Peralta-Videa, J.R.; Gardea-Torresdey, J.L. Toxic effects of copper-based nanoparticles or compounds to lettuce (Lactuca sativa) and alfalfa (Medicago sativa). Environ. Sci. Process Impacts 2015, 17, 177-185. [CrossRef]

51. López-Vargas, E.; Ortiz, H.; Cadenas-Pliego, G.; De Alba Romenus, K.; De la Fuente, M.; Benavides-Mendoza, A.; Juárez Maldonado, A. Foliar Application of Copper Nanoparticles Increases the Fruit Quality and the Content of Bioactive Compounds in Tomatoes. Appl. Sci. 2018, 8, 1020. [CrossRef]

52. Ibrahim, A.S.; Fahmy, A.H.; Ahmed, S.S. Copper nanoparticles elevate regeneration capacity of (Ocimum basilicum L.) plant via somatic embryogenesis. Plant Cell Tissue Organ Cult. (PCTOC) 2019, 136, 41-50. [CrossRef]

53. Genady, E.; Ahmed, S.; Fahmy, A.; Ashour, R. Copper sulfate nanoparticles enhance growth parameters, flavonoid content and antimicrobial activity of Ocimum basilicum Linnaeus. J. Am. Sci. 2017, 13, 108-114. 
54. Shaw, A.K.; Ghosh, S.; Kalaji, H.M.; Bosa, K.; Brestic, M.; Zivcak, M.; Hossain, Z. Nano-CuO stress induced modulation of antioxidative defense and photosynthetic performance of Syrian barley (Hordeum vulgare L.). Environ. Exp. Bot. 2014, $102,37-47$. [CrossRef]

55. Chung, I.-M.; Rekha, K.; Venkidasamy, B.; Thiruvengadam, M. Effect of Copper Oxide Nanoparticles on the Physiology, Bioactive Molecules, and Transcriptional Changes in Brassica rapa ssp. rapa Seedlings. Water Air Soil Pollut. 2019, 230, 48. [CrossRef]

56. Chung, I.-M.; Rajakumar, G.; Subramanian, U.; Venkidasamy, B.; Thiruvengadam, M. Impact of Copper Oxide Nanoparticles on Enhancement of Bioactive Compounds Using Cell Suspension Cultures of Gymnema sylvestre (Retz.) R. Br. Appl. Sci. 2019, 9, 2165. [CrossRef]

57. Laishram, L.; Pant, N.C.; Singh, O.S.; Dhoundiyal, R.; Joshi, K.; Pandey, C. CuO nanoparticle mediated elicitation of polyphenols and antioxidant activity in chicory (Cichorium intybus L.). Int. J. Chem. Stud. 2018, 6, 3270-3276.

58. Singh, O.S.; Pant, N.C.; Laishram, L.; Tewari, M.; Dhoundiyal, R.; Joshi, K.; Pandey, C. Effect of CuO nanoparticles on polyphenols content and antioxidant activity in Ashwagandha (Withania somnifera L. Dunal). J. Pharmacogn. Phytochem. 2018, 7, 3433-3439.

59. Ul Ain, N.; Ul Haq, I.; Abbasi, B.H.; Javed, R.; Zia, M. Influence of PVP/PEG impregnated CuO NPs on physiological and biochemical characteristics of Trigonella foenum-graecum L. IET Nanobiotechnol. 2017, 12, 349-356. [CrossRef]

60. Nair, P.M.G.; Chung, I.M. Impact of copper oxide nanoparticles exposure on Arabidopsis thaliana growth, root system development, root lignificaion, and molecular level changes. Environ. Sci. Pollut. Res. 2014, 21, 12709-12722. [CrossRef]

61. Kurek, J.M.; Krejpcio, Z. The functional and health-promoting properties of Stevia rebaudiana Bertoni and its glycosides with special focus on the antidiabetic potential-A review. J. Funct. Foods 2019, 61, 103465. [CrossRef]

62. Javed, R.; Yucesan, B.; Zia, M.; Gurel, E. Elicitation of Secondary Metabolites in Callus Cultures of Stevia rebaudiana Bertoni Grown Under ZnO and CuO Nanoparticles Stress. Sugar Tech 2018, 20, 194-201. [CrossRef]

63. Ghazal, B.; Saif, S.; Farid, K.; Khan, A.; Rehman, S.; Reshma, A.; Fazal, H.; Ali, M.; Ahmad, A.; Rahman, L. Stimulation of secondary metabolites by copper and gold nanoparticles in submerge adventitious root cultures of Stevia rebaudiana (Bert.). IET Nanobiotechnol. 2018, 12, 569-573. [CrossRef] [PubMed]

64. Shibata, S. A drug over the millennia: Pharmacognosy, chemistry, and pharmacology of licorice. Yakugaku Zasshi 2000, 120, 849-862. [CrossRef] [PubMed]

65. Oloumi, H.; Soltaninejad, R.; Baghizadeh, A. The comparative effects of nano and bulk size particles of $\mathrm{CuO}$ and $\mathrm{ZnO}$ on glycyrrhizin and phenolic compounds contents in Glycyrrhiza glabra L. seedlings. Indian J. Plant Physiol. 2015, $20,157-161$. [CrossRef]

66. Nair, R.; Varghese, S.H.; Nair, B.G.; Maekawa, T.; Yoshida, Y.; Kumar, D.S. Nanoparticulate material delivery to plants. Plant Sci. 2010, 179, 154-163. [CrossRef]

67. Karimi, N.; Behbahani, M.; Dini, G.; Razmjou, A. Enhancing the secondary metabolite and anticancer activity of Echinacea purpurea callus extracts by treatment with biosynthesized ZnO nanoparticles. Adv. Nat. Sci. Nanosci. Nanotechnol. 2018, 9, 045009. [CrossRef]

68. Abbasi, B.H.; Zahir, A.; Ahmad, W.; Nadeem, M.; Giglioli-Guivarc'h, N.; Hano, C. Biogenic zinc oxide nanoparticles-enhanced biosynthesis of lignans and neolignans in cell suspension cultures of Linum usitatissimum L. Artif. Cells Nanomed. Biotechnol. 2019, 47, 1367-1373. [CrossRef]

69. Javed, R.; Usman, M.; Yücesan, B.; Zia, M.; Gürel, E. Effect of zinc oxide (ZnO) nanoparticles on physiology and steviol glycosides production in micropropagated shoots of Stevia rebaudiana Bertoni. Plant Physiol. Biochem. 2017, 110, 94-99. [CrossRef]

70. Chamani, E.; Karimi Ghalehtaki, S.; Mohebodini, M.; Ghanbari, A. The effect of Zinc oxide nano particles and Humic acid on morphological characters and secondary metabolite production in Lilium ledebourii Bioss. Iran. J. Genet. Plant Breed. 2015, 4, 11-19.

71. Raigond, P.; Raigond, B.; Kaundal, B.; Singh, B.; Joshi, A.; Dutt, S. Effect of zinc nanoparticles on antioxidative system of potato plants. J. Environ. Biol. 2017, 38, 435-439. [CrossRef]

72. Velázquez-Gamboa, M.C.; Rodríguez-Hernández, L.; Abud-Archila, M.; Gutiérrez-Miceli, F.A.; González-Mendoza, D.; ValdezSalas, B.; González-Terreros, E.; Luján-Hidalgo, M.C. Agronomic Biofortification of Stevia rebaudiana with Zinc Oxide (ZnO) Phytonanoparticles and Antioxidant Compounds. Sugar Tech 2020, 1-8. [CrossRef]

73. Ahmad, M.A.; Javed, R.; Adeel, M.; Rizwan, M.; Ao, Q.; Yang, Y. Engineered ZnO and CuO Nanoparticles Ameliorate Morphological and Biochemical Response in Tissue Culture Regenerants of Candyleaf (Stevia rebaudiana). Molecules 2020, 25, 1356. [CrossRef] [PubMed]

74. Hussain, F.; Hadi, F.; Akbar, F. Magnesium oxide nanoparticles and thidiazuron enhance lead phytoaccumulation and antioxidative response in Raphanus sativus L. Environ. Sci. Pollut. Res. 2019, 26, 30333-30347. [CrossRef] [PubMed]

75. Baskar, V.; Nayeem, S.; Kuppuraj, S.P.; Muthu, T.; Ramalingam, S. Assessment of the effects of metal oxide nanoparticles on the growth, physiology and metabolic responses in in vitro grown eggplant (Solanum melongena). 3 Biotech 2018, 8, 362. [CrossRef] [PubMed]

76. Moradi, H.; Ghavam, M.; Tavili, A. Study of antioxidant activity and some herbal compounds of Dracocephalum kotschyi Boiss. in different ages of growth. Biotechnol. Rep. 2020, 25, e00408. [CrossRef] [PubMed]

77. Nourozi, E.; Hosseini, B.; Maleki, R.; Abdollahi Mandoulakani, B. Iron oxide nanoparticles: A novel elicitor to enhance anticancer flavonoid production and gene expression in Dracocephalum kotschyi hairy-root cultures. J. Sci. Food Agric. 2019, 99, 6418-6430. [CrossRef] 
78. Mohebodini, M.; Fathi, R.; Mehri, N. Optimization of hairy root induction in chicory (Cichorium intybus L.) and effects of nanoparticles on secondary metabolites accumulation. Iran. J. Genet. Plant Breed. 2017, 6, 60-68.

79. Khan, M.A.; Ali, A.; Mohammad, S.; Ali, H.; Khan, T.; Jan, A.; Ahmad, P. Iron nano modulated growth and biosynthesis of steviol glycosides in Stevia rebaudiana. Plant Cell Tiss. Org. Cult. 2020, 143, 121-130. [CrossRef]

80. Taghizadeh, M.; Nasibi, F.; Kalantari, K.M.; Ghanati, F. Evaluation of secondary metabolites and antioxidant activity in Dracocephalum polychaetum Bornm. cell suspension culture under magnetite nanoparticles and static magnetic field elicitation. Plant Cell Tissue Organ Cult. (PCTOC) 2019, 136, 489-498. [CrossRef]

81. Aladjadjiyan, A. Influence of stationary magnetic field on lentil seeds. Int. Agrophys. 2010, 24, 321-324.

82. Corral-Diaz, B.; Peralta-Videa, J.R.; Alvarez-Parrilla, E.; Rodrigo-García, J.; Morales, M.I.; Osuna-Avila, P.; Niu, G.; HernandezViezcas, J.A.; Gardea-Torresdey, J.L. Cerium oxide nanoparticles alter the antioxidant capacity but do not impact tuber ionome in Raphanus sativus (L). Plant Physiol. Biochem. 2014, 84, 277-285. [CrossRef] [PubMed]

83. Modarresi, M.; Chahardoli, A.; Karimi, N.; Chahardoli, S. Variations of glaucine, quercetin and kaempferol contents in Nigella arvensis against $\mathrm{Al} 2 \mathrm{O} 3, \mathrm{NiO}$, and $\mathrm{TiO} 2$ nanoparticles. Heliyon 2020, 6, e04265. [CrossRef] [PubMed]

84. Al-Oubaidi, H.M.; Kasid, N.M. Increasing (phenolyic and flavoniods compoundes of Cicer arietinum L.) from embryo explant using titanum dioxide nanoparticle in vitro. World J. Pharm. Res. 2015, 4, 1791-1799.

85. Nourozi, E.; Hosseini, B.; Maleki, R.; Mandoulakani, B.A. Pharmaceutical important phenolic compounds overproduction and gene expression analysis in Dracocephalum kotschyi hairy roots elicited by SiO2 nanoparticles. Ind. Crops Prod. 2019, 133, 435-446. [CrossRef]

86. Hedayati, A.; Hosseini, B.; Palazon, J.; Maleki, R. Improved tropane alkaloid production and changes in gene expression in hairy root cultures of two Hyoscyamus species elicited by silicon dioxide nanoparticles. Plant Physiol. Biochem. 2020, 155, 416-428. [CrossRef]

87. Tian, H.; Ghorbanpour, M.; Kariman, K. Manganese oxide nanoparticle-induced changes in growth, redox reactions and elicitation of antioxidant metabolites in deadly nightshade (Atropa belladonna L.). Ind. Crops Prod. 2018, 126, 403-414. [CrossRef]

88. Begum, P.; Fugetsu, B. Phytotoxicity of multi-walled carbon nanotubes on red spinach (Amaranthus tricolor L.) and the role of ascorbic acid as an antioxidant. J. Hazard. Mater. 2012, 243, 212-222. [CrossRef]

89. Ghorbanpour, M.; Hadian, J. Multi-walled carbon nanotubes stimulate callus induction, secondary metabolites biosynthesis and antioxidant capacity in medicinal plant Satureja khuzestanica grown in vitro. Carbon 2015, 94, 749-759. [CrossRef]

90. Samadi, S.; Saharkhiz, M.J.; Azizi, M.; Samiei, L.; Ghorbanpour, M. Multi-walled carbon nanotubes stimulate growth, redox reactions and biosynthesis of antioxidant metabolites in Thymus daenensis celak. in vitro. Chemosphere 2020, 249, 126069. [CrossRef]

91. Rahmani, N.; Radjabian, T.; Soltani, B.M. Impacts of foliar exposure to multi-walled carbon nanotubes on physiological and molecular traits of Salvia verticillata L., as a medicinal plant. Plant Physiol. Biochem. 2020, 150, 27-38. [CrossRef]

92. Gaafar, A.A.; Taha, R.A.; Abou-Baker, N.H.; Shaaban, E.A.; Salama, Z.A. Evaluation of regeneration, active ingredients and antioxidant activities in jojoba tissue cultures as affected by carbon nanotubes. Biosci. Res. 2018, 15, $2383-2392$.

93. Divya, K.; Jisha, M.S. Chitosan nanoparticles preparation and applications. Environ. Chem. Lett. 2018, 16, 101-112. [CrossRef]

94. Ahmad, W.; Zahir, A.; Nadeem, M.; Garros, L.; Drouet, S.; Renouard, S.; Doussot, D.; Giglioli-Guivarc'h, N.; Hano, C.; Abbasi, B.H. Enhanced production of lignans and neolignans in chitosan-treated flax (Linum usitatissimum L.) cell cultures. Process Biochem. 2019, 79, 155-165. [CrossRef]

95. Chandra, S.; Chakraborty, N.; Dasgupta, A.; Sarkar, J.; Panda, K.; Acharya, K. Chitosan nanoparticles: A positive modulator of innate immune responses in plants. Sci. Rep. 2015, 5, 15195. [CrossRef]

96. Schwab, F.; Zhai, G.; Kern, M.; Turner, A.; Schnoor, J.L.; Wiesner, M.R. Barriers, pathways and processes for uptake, translocation and accumulation of nanomaterials in plants-Critical review. Nanotoxicology 2016, 10, 257-278. [CrossRef] [PubMed]

97. Kothari, D.; Lee, W.-D.; Kim, S.-K. Allium Flavonols: Health Benefits, Molecular Targets, and Bioavailability. Antioxidants 2020, 9 , 888. [CrossRef] [PubMed] 